\title{
Broncholithiasis with Recurrent Lithoptysis: A Case Report
}

\author{
Ahmet Bircan $^{\mathrm{a}}$ Duygu Onur ${ }^{\mathrm{a}}$ Aydın Yılmaz \\ ${ }^{\mathrm{a}}$ Department of Pulmonary Medicine, Suleyman Demirel University Faculty of Medicine, Isparta, and ${ }^{\mathrm{b}}$ Ataturk Chest \\ Disease and Thoracic Surgery Research and Training Center, Ankara, Turkey
}

\section{Key Words}

Bronchoscopy · Hemoptysis · Lymph nodes · Tuberculosis · Calculi

\begin{abstract}
Objective: To report a case of broncholithiasis with different types of calculi in the tracheobronchial tree. Clinical Presentation and Intervention: A 50-year-old male who suffered from hemoptysis presented with recurrent broncholith expectoration due to past tuberculous middle lobe syndrome. Bronchoscopic examination revealed loose and embedded broncholiths located at two different bronchi. A surgical resection was suggested, but he refused. Conclusion: The diagnosis of broncholithiasis should be kept in mind in patients who had hemoptysis and calcified mediastinal lymph nodes on thorax computerized tomography, and diagnostic bronchoscopy should be done to prove the relationship of the tracheobronchial tree with a broncholith.
\end{abstract}

(c) 2013 S. Karger AG, Basel

\section{Introduction}

Broncholithiasis is defined as the presence of calculi in the tracheobronchial tree. It is a rare disease but can be characterized by clinical and radiological findings of a calcified lymph node eroding bronchial wall and opening into the bronchial lumen. Here, we report a case of bron- cholithiasis who had different types of calculi in his tracheobronchial tree, and who had recurrent broncholith expectoration (lithoptysis).

\section{Case Report}

A 50-year-old male patient (nonsmoker) was admitted to our outpatient clinic with complaints of hemoptysis for 10 days, and nonspecific nonpleural chest pain. His medical history revealed recurrent hemoptysis attacks and recurrent broncholith expectoration that occurred twice ( 2 years and 25 years ago). Seven years ago, in another hospital, he had right thoracotomy and partial resection of the right middle lobe (RML), due to severe hemoptysis and bronchiectasis. Two years ago, he was admitted to the same institution because of hemoptysis and had a bronchoscopic examination which revealed a foreign body in the RML bronchus. Another surgical operation was recommended, but he did not accept it. When he was admitted to our hospital, physical examination revealed a right thoracotomy scar. Routine hemogram and biochemical tests (serum C-reactive protein level and erythrocyte sedimentation rate) were within normal limits. His sputum was negative for mycobacterial disease. His chest X-ray revealed reticular infiltration extending from the right hilum to the periphery (fig. 1). Thoracic computerized tomography (CT) revealed multiple calcified lymph nodes, located at the right lower paratracheal, right hilar and subcarinal areas, surrounding the RML (fig. 2a, b). Flexible bronchoscopic examination revealed white, solid and sharp-edged lesions located at the distal portion of the RML bronchus and the anterior segment of right upper lobe (RUL) bronchus (fig. 3a, b). When we tried to remove the lesion located in the RML, a small amount of hemorrhage occurred. Bronchoscopic approach to other lesion located at the RUL was also not possible. The diagnosis of broncholithiasis was made and for further evaluation and

\section{KARGER}

E-Mail karger@karger.com www.karger.com/mpp
(C) 2013 S. Karger AG, Base 1011-7571/14/0231-0083\$39.50/0

Karger

Open access

This is an Open Access article licensed under the terms of the Creative Commons Attribution-NonCommercial 3.0 Unported license (CC BY-NC) (www.karger.com/OA-license), applicable to the online version of the article only. Distribution permitted for non-commercial purposes only.
Assoc. Prof. Ahmet Bircan, MD

Department of Pulmonary Medicine

Suleyman Demirel University Faculty of Medicine

TR-32260 Isparta (Turkey)

E-Mail ahbircan@yahoo.com 


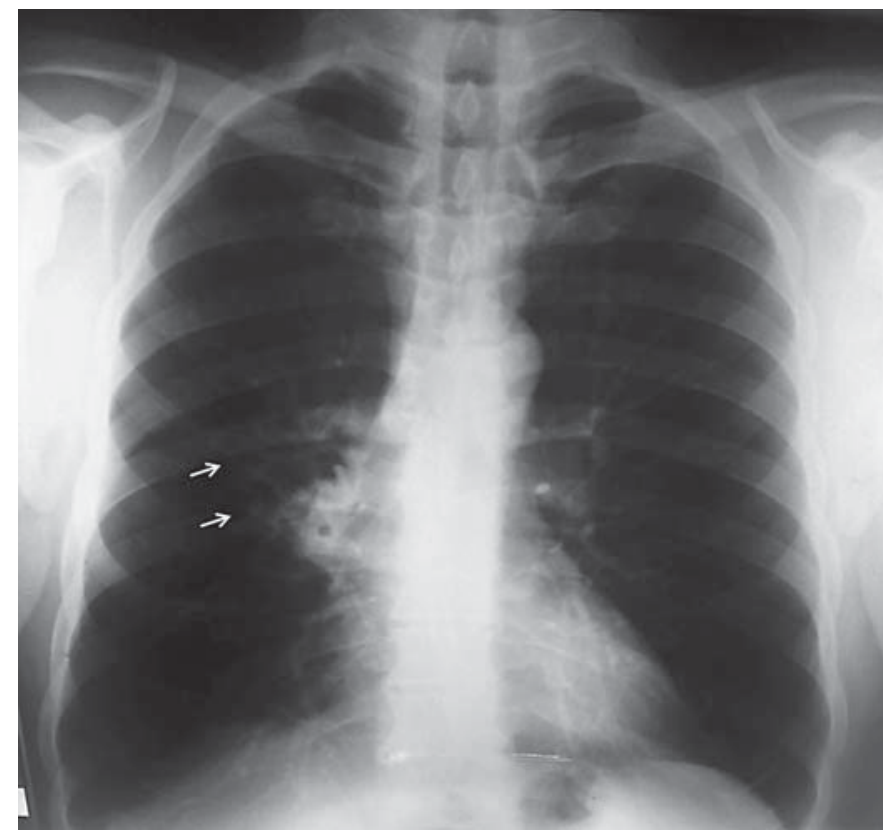

Fig. 1. Chest X-ray showing coarse reticular infiltration extending from the right hilum to the periphery (arrows).

surgical treatment (right lobectomy), he was referred to another hospital where advanced thoracic surgery facilities are available. There, he had another bronchoscopic examination, traditional rigid bronchoscopy not combined with a flexible bronchoscope, reporting no endobronchial abnormality. He was then readmitted to our hospital. Although he denied a new episode of lithoptysis, he again underwent a bronchoscopic examination with a flexible bronchoscope to protect him from further unnecessary surgery. After we were sure that the broncholiths were still present, we suggested to him a surgical treatment, right middle lobectomy, but he refused.

\section{Discussion}

Broncholithiasis is caused by a calcified lymph node eroding bronchial wall and an opening into the bronchial lumen. Granulomatous lymphadenitis caused by mycobacterial infections is the most common cause of broncholithiasis all over the world. Silicosis, malignancy and granulomatous fungal infections are other rare causes [1]. In our case, although he had no current or past history of tuberculosis, the middle lobe syndrome was due to tuberculous lymphadenitis. Although a broncholith seldom causes symptoms, chronic cough, fever, hemoptysis, localized wheezing, chest pain and lithoptysis can be seen in the clinical course of disease according to
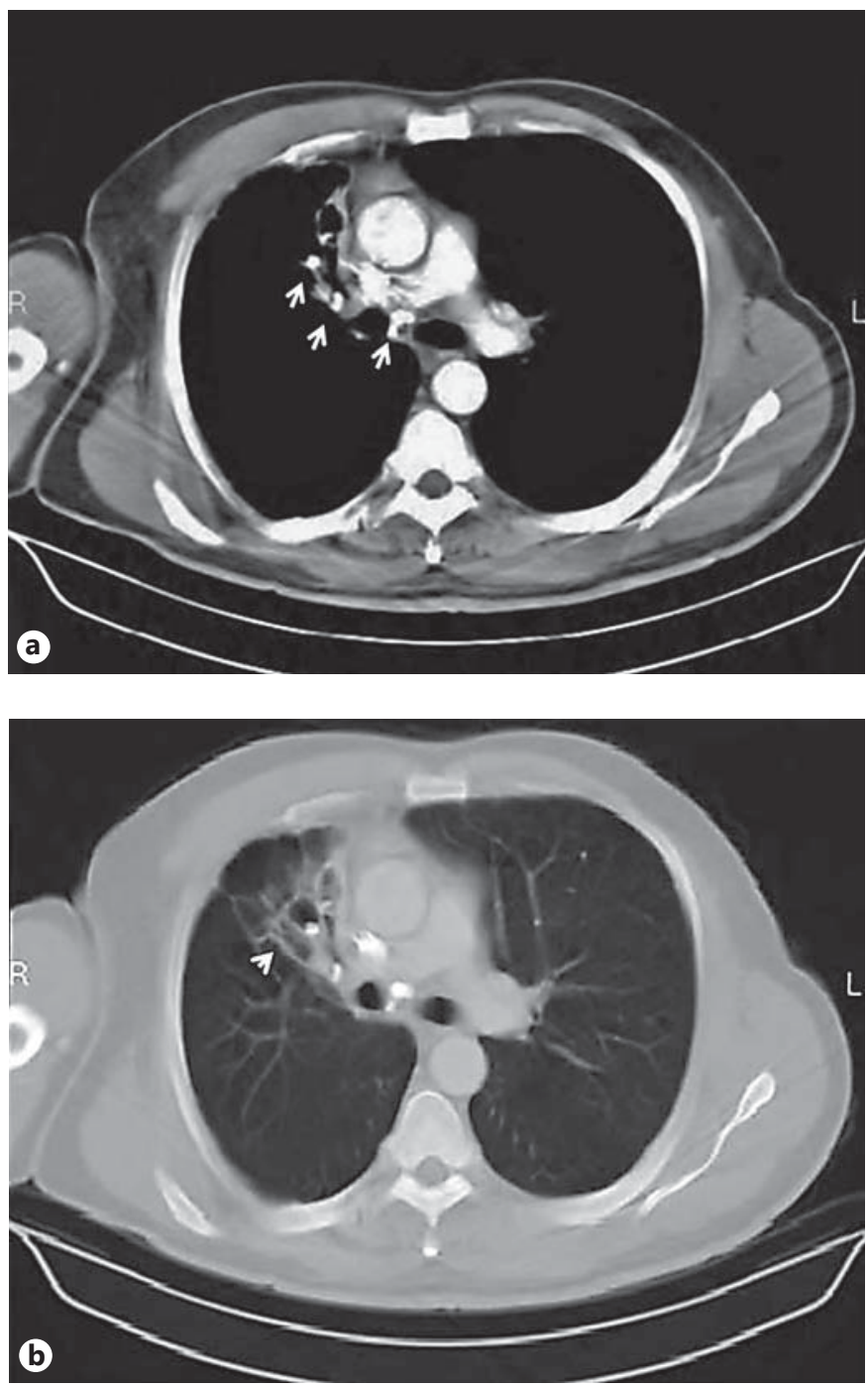

Fig. 2. Thoracic CT sections showing multiple calcified lymph nodes located $\mathbf{a}$ at the right hilar and subcarinal areas surrounding the RML (arrows) and $\mathbf{b}$ a destructed RML (arrowhead).

its location. Our patient had recurrent attacks of hemoptysis and lithoptysis. Lithoptysis, known as a pathognomonic sign, is very rare, and once it happens the patient's other symptoms related to bronchial obstruction may regress.

Flexible bronchoscopy and thorax CT are the most important diagnostic tools to allow the assessment of the relationship between calcification and bronchus [2]. The bronchoscopic findings of this case were strongly compatible with the characteristic endoscopic features for this disease. Typically, we saw irregular-shaped, gray-white colored broncholiths at the bronchi of RML and the an- 
Fig. 3. Anterior segment of the RUL bronchus (a) and distal portion of the middle lobe bronchus (b).
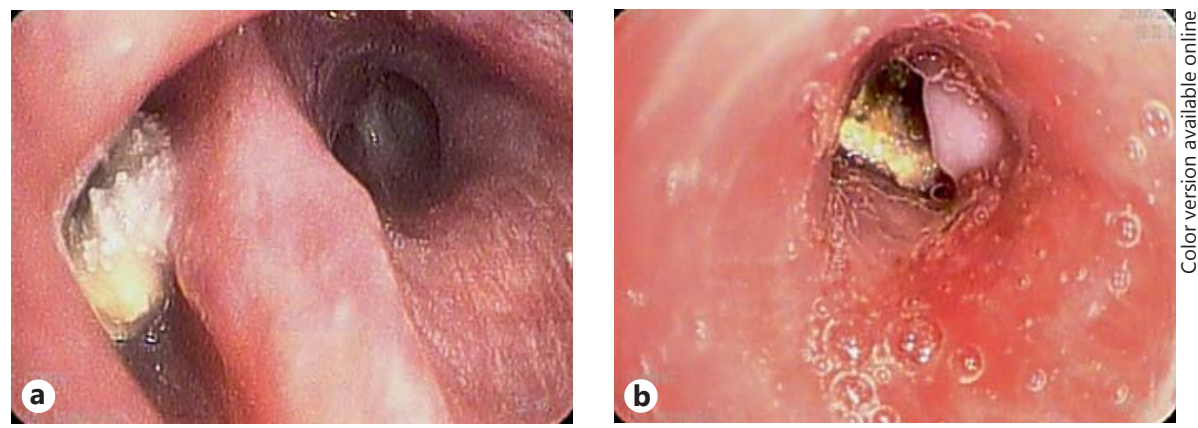

terior segment of RUL, which have been known as preferential sites of broncholiths because of airway anatomy and lymph node distribution [3].

The most common complications of the disease are related to bronchus obstruction such as hyperinflation, atelectasis, bronchiectasis and obstructive pneumonia. Rarely, bronchogenic dissemination of tuberculous lymphadenitis and lung abscesses secondary to bronchoesophageal and bronchomediastinal fistulas may be seen $[1,3]$. In our case, while all complications were seem to be related to the broncholith located at the bronchus of RML, the other one at the RUL was the most likely responsible for recurrent lithoptysis.

The most important therapeutic issue about the fate of broncholiths is to decide whether to do a follow-up, bronchoscopic removal or surgical resection. In general, broncholiths can be broken down and removed with a large broad-rim forceps via a large channel rigid bronchoscopy combined with flexible bronchoscopy, in contrast to our case $[4,5]$. For the symptomatic and loose broncholiths in uncomplicated cases, bronchoscopic removal is worth trying to eliminate the necessity of thoracotomy. All loose broncholiths and about half of the embedded ones can be successfully removed bronchoscopically without serious complications [4]. It should be remembered that a severe hemoptysis can occur due to erosion of a branch of the pulmonary artery during the procedure. Broncholiths can also be removed using cryotherapy or laser photocoagulation especially in centrally located ones [4-7]. In our case it was not appropriate to bronchoscopically remove the broncholiths because one was tightly embedded to the bronchial wall and the other was not approachable via a flexible bronchoscope. Hence the patient was referred to a specialized hospital for surgical removal of the broncholiths that were tightly embedded into the bronchial wall, because this is the preferential therapeutic approach [5, $8,9]$.

\section{Conclusion}

This was a case of broncholithiasis with recurrent lithoptysis with different types of endoscopic appearance of the broncholith - loose and embedded. The diagnosis of broncholithiasis should be kept in mind in patients who had previous tuberculosis and/or calcified lymph nodes adjacent to the bronchus in thorax CT, and bronchoscopic examination should be done for both diagnosis and possible bronchoscopic removal.

\section{References}

1 De S, De S: Broncholithiasis. Lung India 2008; 25:152-154.

2 Conces DJ, Tarver RD, Vix VA: Broncholithiasis: CT features in 15 patients. Am J Roentgenol 1991;157:249-253.

-3 Galdermans D, Verhaert J, Van Meerbeeck J, et al: Broncholithiasis: present clinical spectrum. Respir Med 1990;84:155-156.

4 Olson EJ, Utz JP, Prakash UBS: Therapeutic bronchoscopy in broncholithiasis. Am J Respir Crit Care Med 1999;160:766-770.
5 Menivale F, Deslee G, Vallerand H, et al: Therapeutic management of broncholithiasis. Ann Thorac Surg 2005;79:1774-1776.

6 Reddy AJ, Govert JA, Sporn TA, et al: Broncholith removal using cryotherapy during flexible bronchoscopy: a case report. Chest 2007;132:1661-1663.

7 Ferguson JS, Rippentrop JM, Fallon B, et al: Management of obstructing pulmonary broncholithiasis with three-dimensional imaging and holmium laser lithotripsy. Chest 2006;130:909-912. 